\title{
ERRATUM
}

K. H. George $\cdot$ H. K. Schminke

\section{Harpacticoida (Crustacea, Copepoda) of the Great Meteor Seamount, with first conclusions as to the origin of the plateau fauna}

Published online: 21 April 2005

(C) Springer-Verlag 2005

Marine Biology (2002) 141:887-895

The above article appeared in:

Marine Biology (2002) 141: 887-895 and not in volume 144, as indicated in the source line of both the print and pdf online versions.

The online version of the original article can be found at http:// dx.doi.org/10.1007/s00227-002-0878-6

K. H. George $(\square) \cdot$ H. K. Schminke

Arbeitsgruppe Zoosystematik und Morphologie,

Fachbereich Biologie, Geo- und Umweltwissenschaften

der Carl von Ossietzky-Universität,

26111 Oldenburg, Germany

E-mail: kgeorge@senckenberg.de

Present address: K. H. George

DZMB, Schleusenstr. 1,

26382 Wilhelmshaven, Germany 